\title{
Antibacterial Susceptibility and Resistance
}

\section{Pattern of Organisms Isolated from Rectal Swab of Chicken}

\author{
Olateru Comfort T.;Popoola, B. M.;Hassan F. A. \\ Department of Microbiology, University of Ibadan, Ibadan, Nigeria
}

\begin{abstract}
Resistance to antibiotics is a serious matter of concern for Public and threats to the successful treatment of miscrobial disease. The prevalence of some enterobacteriaceae such as Escherichia coli and Salmonella spp resistant to antimicrobial agents is increasing. This study is intended to determine susceptibility and resistance pattern of pathogenic isolates from the rectal swabs of chicken to 8 antibiotics.

Hundred (100) rectal swabs of chickens were collected randomly from three different farms; a farm at Montan, Awotan, Apete and Apata all in Ibadan Metropolis of Oyo State. Isolation and identification of organisms were done using standard bacteriological techniques. Antimicrobial susceptibility test was performed following standard protocol.

A total of 93 bacterial isolates were obtained from the hundred (100) rectal swaps of chicken. The isolates Escherichia Coli, Staphylococcus aureus and Salmonella spp. and their percentage of prevalence are 54, 43 and 3. Antibiotic susceptibility tests carried out on the isolates showed that most of the isolates were resistant to ofloxacin, cloxacillin and Augumentin, while almost all the isolates in this study are sensitive to gentamicin. Erythromycin did not have any effect on any of the bacterial isolates.

Bacterial isolates obtained in the study area were multi drug resistant and this suggests that the chickens are important reservoir of antimicrobial resistant organism which is a major public health concern.
\end{abstract}

Keywords-Antimicrobial, Resistance, Bacterial isolates.

\section{INTRODUCTION}

The control of microorganisms is critical for the prevention and treatment of disease. Microorganisms grow on and within other organisms and microbial colonization can lead to disease, disability and death. Thus, the control on destruction of microorganisms residing within the bodies of humans and other animals is of great importance.

An antibacterial agent is a compound or substance that kills or slows down the growth of bacteria. The term is often synonymously used with the term (antibiotics), today however, with increased knowledge of the causative agents of various infectious diseases, antibiotics have come to denote a broader range of antimicrobial compounds including antifungal and other compounds.

In several countries, antibiotics such as penicillin, erythromycin and tetracycline are approved for the growth promotion as well as therapeutic use in animals, many of the antibiotics that are given to animals are closely related to medically important human drugs. Thus it is possible that the indiscriminate use of antibiotics of non-human use e.g. as addictive can lead to the development of resistance which could then be passed to human pathogens.

Food animals harbor food borne pathogens and act as source of contamination, which is important in the spread of Salmonella and Escherichia Coli in human, (Acha and Szyfres, 2001; Apajalahti et al., 2004 and White et al., 2001.). Staphylococcal infections are frequently treated with antibiotics and consequently resistance to it and or acquired resistance develop (Normand et al., 2000). The emergence of resistance in enteric pathogens to different antimicrobial agents in farming communities will adversely affect the availability of antimicrobial therapies available for use (Wagener et al., 1999, Witte et al., 2000).

The emergence and widespread of antimicrobial resistant Escherichia Coli and Salmonella strains in chickens and humans may be associated with the indiscrimate use of antimicrobials both in animal and human treatments (Molla et al., 2003).Antibiotic resistance in these bacterial is often mediated by Plasmids, some of which are self-transmissible (Dufrenne et al., 2001; Adesiyun and Oni, 1989; Bebora et al, 1994; Robab and Azadeg, 2003; Kariuki et al., 2005), whereas others maybe co-transferred by conjugative Plasmids (Robab and Azadeh, 2003; Kariuki et al., 2005).

However, the principle behind the development of resistance is that bacteria in the guts of humans and animals are subjected to different types, concentrations and frequencies of antimicrobial agents. Overtime, selective pressure selects resistant bacteria that have specific 
fingerprints for resistance to antimicrobial agents that have been used (Prescote et al., 2000; Troy et al., 2002).

Hence this work was carried out to isolate Pathogenic bacteria from the rectal swabs of chicken and to determine the antibiotics susceptibility and resistance pattern isolates to 8 antibiotics.

\section{MATERIALS AND METHODS}

\section{Sample collection}

Hudnred rectal swabs of chickens were collected randomly from three different farms; the farm at Monatan, Awotan, Apete and Apata all in Ibadan metropolis in Oyo State. The rectal swabs were all transferred into sterile peptone water in McCartney bottles and were transported into the laboratory immediately for microbiological analysis.

\section{Preparation of media}

The media were prepared according to the manufacturers' instruction. These media are as follows; Eosin Methylene Blue (EMB), Nutrient Agar (NA), Salmonella Shigella Agar (SSA) and Mannitol Salt Agar (MSA).

\section{Isolation of microorganism}

The rectal swabs collected were streaked on the surface of the agar-plates. The plates were then incubated at $37^{\circ} \mathrm{C}$ for 18-24hours. The isolates on each plate were sub-cultured on the different agar plates to obtain pure cultures.

Each of the rectal swab collected was streaked on the surface of each agar plate. The plates were incubated at $37^{\circ} \mathrm{C}$ for 18-24hours. The isolates on each plate were subcultured on the different agar plates to obtain pure cultures.

\section{Identification of Bacterial Isolates}

Conventional isolation techniques such as growth on selective media, gram staining and biochemical tests were utilized for the identification for the different bacterial isolates.

The isolates were also subjected to various biochemical tests to determine their probable identity. The result of each test was recorded and the probable identity of the isolate determined using Khoos and Schlenfer (1975) and Bergey's manual of systematic bacteriology (Cheesbrough, 2000).

Antibiotic Susceptibility Test: The bacterial isolates were tested for their susceptibility to antimicrobial agents using the agar disc-diffusion method of Piddock (1990).

All the isolates were screened for their antibiotic susceptibility to routinely used antibiotics such as Gentamicin, Ceftazidime, Cloxacillin, Ofloxacin, Cefunxine, Erythromycin, Cefixime and Augmentin,obtained from Abtek biologicals.

Gram positive and negative antibiotics discs were placed and pressed on already prepared sterile solidified Muller Hinton agar with a sterile forceps on seeded agar-plates to ensure complete contact with the agar.
The plates were incubated for 24 hours at $37^{\circ} \mathrm{C}$ for all the isolates. Clear zone of inhibition around the antibiotic disc on the plate were measured in millimeter. The clear zone indicated the relative susceptibility of the isolate of each antibiotic.

\section{RESULTS}

A total of 144 Escherichia coli,104 Staphylocccus aureus and 24 Salmonella spp were isolated from the three poultry farms (Table 1). The percentage prevalence of Escherichia coli isolated was 54, Staphylocccus aureus was 43, while Salmonella spp had the least prevalence of 3.

Table 2 shows the result of the percentage resistance of the bacterial isolates to each of the antibiotics. Most of the bacterial isolates were resistant to Ofloxacin, Cloxacillin and Augmentin. While almost all the Isolates in this study were sensitive to Gentamicin. Erythromycin did not have effect on any of the bacterial isolates. $60 \%$ of the isolates were resistant to at least 4 antibiotic agents. $70 \%$ of Salmonella spp were resistant to 5 antibiotics agents while $90 \%$ of Escherichia coli were resistant to at least 5 antibacterial agents.

Table.1: Isolates from Selected Commercial Poultry Farms in Ibadan Metropolis.

\begin{tabular}{|l|l|l|l|}
\hline \multirow{2}{*}{$\begin{array}{l}\text { Source } \\
\text { (FARM) }\end{array}$} & \multicolumn{3}{|c|}{ Organisms Isolated/ Numbers of } \\
Organisms
\end{tabular}

Table.2: Percentage of Organisms Resistant to each Antibiotics Escherichia coli, Staphyloccus. aureus, Salmonella spp.

\begin{tabular}{|c|c|c|c|}
\hline \multirow[t]{2}{*}{ Antibiotics } & \multicolumn{3}{|c|}{$\begin{array}{llll}\text { Organisms } & \text { Isolated/ Numbers } & \text { of } \\
\text { Organisms } & & \end{array}$} \\
\hline & $\begin{array}{l}\text { Staphylocccu } \\
\text { s aureus }\end{array}$ & $\begin{array}{l}\text { Escherichiaco } \\
\text { li }\end{array}$ & $\begin{array}{l}\text { Salmonell } \\
\text { a spp }\end{array}$ \\
\hline Ceftazidime & 75 & 65 & 8 \\
\hline Cloxacillin & 95 & 90 & 84 \\
\hline Gentamicin & 0 & 10 & 5 \\
\hline Ofloxacin & 90 & 45 & 70 \\
\hline Cefurxine & 90 & 90 & 84 \\
\hline $\begin{array}{l}\text { Erythromyci } \\
\mathrm{n}\end{array}$ & 100 & 90 & 95 \\
\hline Cefixime & 90 & 84 & 41 \\
\hline Augmentin & 85 & 70 & 60 \\
\hline
\end{tabular}




\section{DISCUSSION}

The microbial isolates identified in this study are Staphylococcus aureus, Escherichia coli and Samonella spp. Staphylococcus aureus and Escherichia coli appeared to be the most prevalent bacterial species isolated. Staphylococcus aureus is known to be easily carried in the nasopharynx, throat, skin, cuts, boils, nails and as such can easily contribute to the normal microflora (Ekhaise et al., 2008; Yaqub et al., 2012).

Salmonella is the least bacterial isolate isolated from the chickens and this trend can be attributed to the good Salmonella control programme practiced by most farms as examination of food to detect Salmonella is routinely carried out for food safety and food-borne disease surveillance.

The lower rates of Salmonella was similar to those reported by Robert et al., 2002; Yaqub et al., 2012 and was in contrast to the report of Davies et al., 1997.

The result of this study revealed the presence of multi-drug resistant bacteria from chickens. All isolates showed high resistance to Cloxacillin while the isolates are sensitive to Gentamicin. The result of this study clearly identifies Gentaniclin as a good choice antibiotic for treatment of infection in this study. Also all Escherichia coli and Salmonella sp.isolated in this study were found to be resistant to 4 or more antibacterial agents tested in this study which is supported by earlier report of Overdevett $e t$ al., 2011, Yaqub et al., 2012 that drug resistance in enterobacteriacea has increased dramatically during the past decade.

The increase being attributed to increased prevalence of extended spectrum $\quad \beta$-lactamase producing enterobacteriaceae.

In addition, these results provided evidence that there is an increased emergence of antibiotic resistance for commensal bacterial isolates, a finding which is in agreement with the earlier reports of Chukwendu et al., 2008 who found increasingly emergence of antibiotic resistance phenotypes in both clinically relevant strains and normal commensal macrobiotic. The findings in the investigation emphasize the importance of studying multiple genera of bacteria from different animals as sources of human exposure to antibiotic resistance strains.

Therefore, not only that the chickens are at risk, poultry workers and consumers are equally exposed to serious hazards due to multi-drug resistance bacteria.

This calls for urgent intervention by regulatory agencies to limit the emergence and spread of these bacteria as well as prudent use of antibacterial agents among farmers in Nigeria.

\section{REFERENCES}

[1] Acha, P.N. and Szyfres B. 2001. Zoonoses and Communicable disease common to man and animals. Third Edition, Washington DC: Pan American Health Organization. 233-246.

[2] Adesiyun, A.A. and Oni, O.O. 1989. Prevalence and antibiograms of Salmonella in Slaughtered cattle, slaughter areas and effluents in Zaria abattoir. Nigeria Journal food protection. 52: 232-235.

[3] Apajalahti, J. Kettunem, A. and Graham, H. 2004. Characteristics of the gastrointestinal microbial communities, with special reference to the chicken. World's Poultry Science Journal 60: 223-232.

[4] Bebora, I.C., Oundo, O.J. and Yamamoto, H. 1994. Resistance of Escherichia coli strains recovered from chickens to antibiotics with particular reference to Trimethoprim-Sulphamethoxazole (Septrin). East Africa Med. 71: 624-627.

[5] Dufrenne, J., Wilma, R., Delfgouvan Ash, E., Frans Van Leusden and Rob de Jouge. 2001. Quantification of the contamination of chicken and chicken products in the Netherlands with Salmonella and Campylobacter. Journal Food protection. 64: 538-554

[6] Kariuki, S., Gunturu, R. and Nyamburak. 2005. Increasing prevalence of multidrug-resistant nontyphoidal salmonellae, Kenya, 1994-2003. International Journal Antimicrobial Agents. 25: 36-43

[7] Manie, T., Khan, S. and Brozel, V.S. 1998. Antimicrobial resistance of bacteria Isolated from slaughtered and retail chickens in South Africa. Letter Application Microbial. 26: 253-258.

[8] Molla, B., Mesfin, A. and Alemaychu, D. 2003. Multiple antimicrobial resistant Salmonella Serotypes isolated from chicken carcass and giblets in Debrezeit and Addis Ababa, Ethiopia. Ethiopian Journal Health Dev. 17: 131-149

[9] McEwen, S.A. and Fedorka-Cray, P.J. 2002. Antimicrobial use and resistance in animals. Clinical Infect. Disease. 34: 93-106.

[10] Prescott, J.F., Baggot, J.D. and Walker, R.D. 2000. Antimicrobial therapy in veterinary epidemiology, 3rd ed. Iowa State University Press, Ames.

[11]Robab, R.T. and Azadeh, N. 2003. Isolation, Identification and antimicrobial resistance patterns of E.coli isolated from chicken flocks. Iranian J. Pharm. Therapeutics. 2: 39-42.

[12] White, D.G., Zhao, S. and Sudler, R. 2001. The Isolation of antibiotic resistant Salmonella from retail ground meats. Microbes Infect, 345:1147-1154

[13] Troy, M.S., Rose, J.B., Jenkins, T.M., Farrah, S.R. and Lukasik, J. 2002. Microbial source tracking: current 
methodology and future directions. Appl. Environment Microbiology. 68: 5796-5803. \{PMC free article\} (PubMed).

[14] Von Baum, H. and Marre, R. 2005. Antimicrobial resistance of Escherichia coli and Therapeutic Implications. International Journal of Medical Microbial. 295:503-511 